33. Stone JC, Hannah A, Nagar N. Dental occlusion and temporomandibular disorders. Evid Based Dent 2017; 18: 86-87. doi: 10.1038/sj.ebd.6401258. PubMedPMID: 29075035.

34. Manfredini D, Lombardo L, Siciliani G.

Temporomandibular disorders and dental occlusion. A systematic review of association studies: end of an era? J Oral Rehabil 2017; 44: 908-923. doi: 10.1111/joor.12531. Epub 2017 Jul 2.Review. PubMed PMID: 28600812.

35. Ferrailo DM, Veitz-Keenan A. No clinical quantifiable benefits between non-surgical and surgical endodontic treatment. Evid Based Dent 2017; 18: 75-76. doi: 10.1038/sj.ebd.6401254. PubMed
PMID: 29075023.

36. Del Fabbro M, Corbella S, Sequeira-Byron P, et al. Endodontic procedures for retreatment of periapical lesions. Cochrane Database Syst Rev 2016; 10: CD005511. Review. PubMed PMID:27759881.

37. Iheozor-Ejiofor Z, Middleton P, Esposito M, Glenny AM. Treating periodontal disease for preventing adverse birth outcomes in pregnant women. Cochrane Database Syst Rev 2017; 6: CD005297. doi: 10.1002/14651858.CD005297.pub3.Review. PubMed PMID: 28605006.

38. Spivakovsky S. Periodontal treatment for the prevention of adverse birth outcomes. Evid Based Dent 2018; 19: 12-13. doi: 10.1038/ sj.ebd.6401286. PubMed PMID: 29568020.

39. Madurantakam $P$. Which surgical approach for palatally displaced canines? Evid Based Dent 2018; 19: 20-21. doi: $10.1038 /$ sj.ebd.6401290. PubMed PMID:29568023.

40. Parkin N, Benson PE, Thind B, Shah A, Khalil I, Ghafoor $S$. Open versus closed surgical exposure of canine teeth that are displaced in the roof of the mouth. Cochrane Database Syst Rev 2017; 8: CD006966. doi: 10.1002/14651858.CD006966. pub3. Review. PubMed PMID: 28828758.

Evidence-Based Dentistry (2019) 20, 4-6. doi:10.1038/s41432-019-0003-z

\title{
Evidence-based Dentistry Journal appoints new editor
}

Professor Elizabeth Kay has been appointed as the new editor of Evidence-Based Dentistry $(E B D)$, a BDJ Portfolio journal.

Kay, who qualified from Edinburgh Dental School in 1982, has a long and distinguished career in dental public health and dental research and is a long- standing member of the $B D J$ Editorial Board. She is the author of 200 research and professional papers, six books and two book chapters, and has previously been Scientific Advisor to the BDA.

In 2017 Kay was awarded an MBE in recognition of her services to dental education and is currently the Foundation Dean at the Peninsula Dental School at Plymouth University and Faculty Associate Dean for Equality and Inclusion. She will take over the position from the current editor with the June 2019 issue.

'I'm really excited about the new post and to have the privilege of working with some excellent people,' said Kay.
'I have spent quite a long career trying to do research and translate it so that it's relevant to practitioners who are delivering good dental care to the population.

'I've been a great proponent of evidencebased practice and the evidence base being used properly ever since I did my PhD. I've been very involved with NICE [National Institute for Health and Care Excellence] so I'm very used to reviewing and trying to pull together complex and complicated and sometimes conflicting evidence and that's a real role for the journal of Evidence-Based Dentistry.'

Stephen Hancocks, Editor-in-Chief of the $B D J$ welcomed the appointment, saying: 'Liz is a great fit as the next editor of $E B D$ and I am delighted that she will be working with us to make even more of the journal based on its strong foundation and robust reputation.'

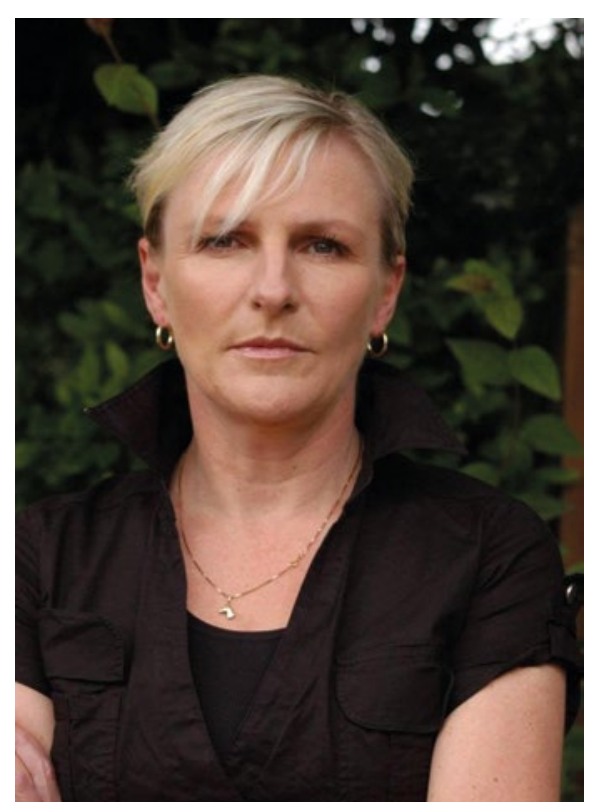

Professor Liz Kay

Evidence-Based Dentistry (2019) 20, 6. doi: 10.1007/s41432-019-0017-6 